\title{
Regional Hydrogeochemical Mapping for Environmental Studies in the Mineralized Lom Basin, East Cameroon: A Pre-industrial Mining Survey
}

\author{
Mumbfu Ernestine Mimba ${ }^{1,2,{ }^{*} \text {, Takeshi Ohba }}{ }^{1}$, Salomon César Nguemhe Fils ${ }^{2}$, \\ Mengnjo Jude Wirmvem ${ }^{2}$, Edith Etakah Bate Tibang ${ }^{2}$, Melvin Tamta Nforba ${ }^{3}$, Festus Togwa Aka ${ }^{2}$ \\ ${ }^{1}$ Department of Chemistry, School of Science and Technology, Tokai University, Hiratsuka, Japan \\ ${ }^{2}$ Institute of Geological and Mining Research (IRGM), Yaounde, Cameroon \\ ${ }^{3}$ School of Geology and Mining Engineering, University of Ngaoundere, Ngaoundere, Cameroon
}

Email address:

mmimba2000@yahoo (M. E. Mimba), volcano.ohba@gmail.com (T. Ohba), cefils1@yahoo.fr (S. C. Nguemhe Fils), judevomayahoo.co.uk (M. J. Wirmvem), edithetakah@yahoo.com (E. E. B. Tibang), nforbamel@gmail.com (M. T. Nforba), akatongwa@yahoo.com (F. T. Aka)

${ }^{*}$ Corresponding author

\section{To cite this article:}

Mumbfu Ernestine Mimba, Takeshi Ohba, Salomon César Nguemhe Fils, Mengnjo Jude Wirmvem, Edith Etakah Bate Tibang, Melvin Tamta Nforba, Festus Togwa Aka. Regional Hydrogeochemical Mapping for Environmental Studies in the Mineralized Lom Basin, East Cameroon: A Pre-industrial Mining Survey. Hydrology. Vol. 5, No. 2, 2017, pp. 15-31. doi: 10.11648/j.hyd.20170502.11

Received: April 19, 2017; Accepted: April 27, 2017; Published: June 26, 2017

\begin{abstract}
The present study is the first appraisal of regional hydrogeochemical programme for environmental assessment of the mineralized Lom Basin in East Cameroon. Fifty-two streamwater samples were collected and analysed for major cations $\left(\mathrm{Ca}^{2+}, \mathrm{Mg}^{2+}, \mathrm{Na}^{+}, \mathrm{K}^{+}\right)$and major anions $\left(\mathrm{HCO}_{3}^{-}, \mathrm{F}^{-}, \mathrm{Cl}^{-}, \mathrm{NO}_{2}^{-}, \mathrm{NO}_{3}^{-}, \mathrm{Br}^{-}, \mathrm{PO}_{4}{ }^{3-}, \mathrm{SO}_{4}{ }^{2-}\right)$. Calcium and $\mathrm{HCO}_{3}^{-}$were the dominant ions. The chemical facies for the surface water were $\mathrm{CaHCO}_{3}$ and $\mathrm{NaHCO}_{3}$ types indicating a fresh water source. Major ion geochemistry demonstrated the potential to discriminate between natural and anthropogenic origins. Calcium ion, $\mathrm{Mg}^{2+}, \mathrm{Na}^{+}, \mathrm{K}^{+}$and $\mathrm{HCO}_{3}{ }^{-}$had similar distribution trends reflecting weathering from the parent rocks. Sulphate distribution correlated with the occurrence of sulphide minerals associated with hydrothermal gold mineralization in the area while the distribution patterns of $\mathrm{NO}_{3}{ }^{-}$and $\mathrm{Cl}^{-}$reflected pollution from domestic activities within the municipality. Overall, the chemistry of stream water in the Lom Basin is mainly controlled by silicate weathering with only minor anthropogenic influence. This study forms an analogue for hydrogeochemical mapping in other mineralized terrains in Cameroon.
\end{abstract}

Keywords: Hydrogeochemical Survey, Major Ions, Provenance, Lom Basin, Cameroon

\section{Introduction}

Geochemical mapping is crucial in identifying sources of elements for both mineral exploration and environmental monitoring [1-2]. Hydrogeochemical mapping, an integral part of most regional and local mapping surveys [3-4], is particularly useful in mapping a drainage basin that includes a proposed mine site [5]. The Lom Basin in East Cameroon is heavily mineralized especially in gold owing to its regional geological setting. Also, it has a long artisanal and semimechanized mining history and is currently a target for industrialized mining. Consequently, research reporting the rock type, age, and the formation history or the reconnaissance gold investigations in this region are numerous [6-9]. Despite this extensive coverage, there is no available data on the chemical composition of streamwater required to establish quality criteria for water in the area. Surface water assessment is of considerable importance especially in areas where indiscriminate disposal of domestic wastes and informal artisanal mining are practised. Water quality also plays a vital role in promoting the standard of human health.

Water is the principal transport pathway for elements derived from the chemical weathering of mineralized rocks and dissolved ion contents in natural waters are routinely 
used to evaluate the surface water quality [10]. Thus, the chemical composition of streams draining a basin is fundamental for preparing regional geochemical baseline maps. Here, baseline refers to the elemental concentration levels in a medium at a particular period [11-12]. These background levels in surface water can be of natural or anthropogenic origin and distinguishing their sources can be quite challenging. Multivariate statistical procedures have often been used to discriminate between patterns of natural and anthropogenic origin [12]. Hence, it is imperative to take into account the origin of the occurrence and concentrations of the dissolved elements for environmental legislation and regulation [13].

This study presents a regional hydrogeochemical baseline prior to industrial mining in the Lom Basin. Other goals are (a) to distinguish between natural and anthropogenic sources of dissolved ions through a systematic sampling of streamwater draining the catchment, (b) to produce geochemical maps of dissolved ions in the area. These data provide information necessary for setting guidelines and legal standards in the region. Moreover, this study forms a reference for hydrogeochemical mapping in other mineralized areas in Cameroon.

\section{Study Area}

The Lom Basin consists largely of monotonous, gently undulating hills of altitude between 600 and $1100 \mathrm{~m}$. Such topography has resulted in a well-developed dendritic drainage system. Streams within the study area rise from the hills, flow in a general south-west direction and discharge into the Lom River (Figure 1) which eventually empties into the Atlantic Ocean. The area has a hot and humid equatorial climate characterised by a long dry season from December to April, light wet season from May to June, short dry season between July and October and a heavy rainy season from October to November. The average annual rainfall varies from 1500-2000 mm. High temperatures are recorded between January and February, and the mean temperature is around $24.7^{\circ} \mathrm{C}$. Shrubs and herbaceous savanna are the dominant vegetation cover which gives way to an evergreen forest further down south.
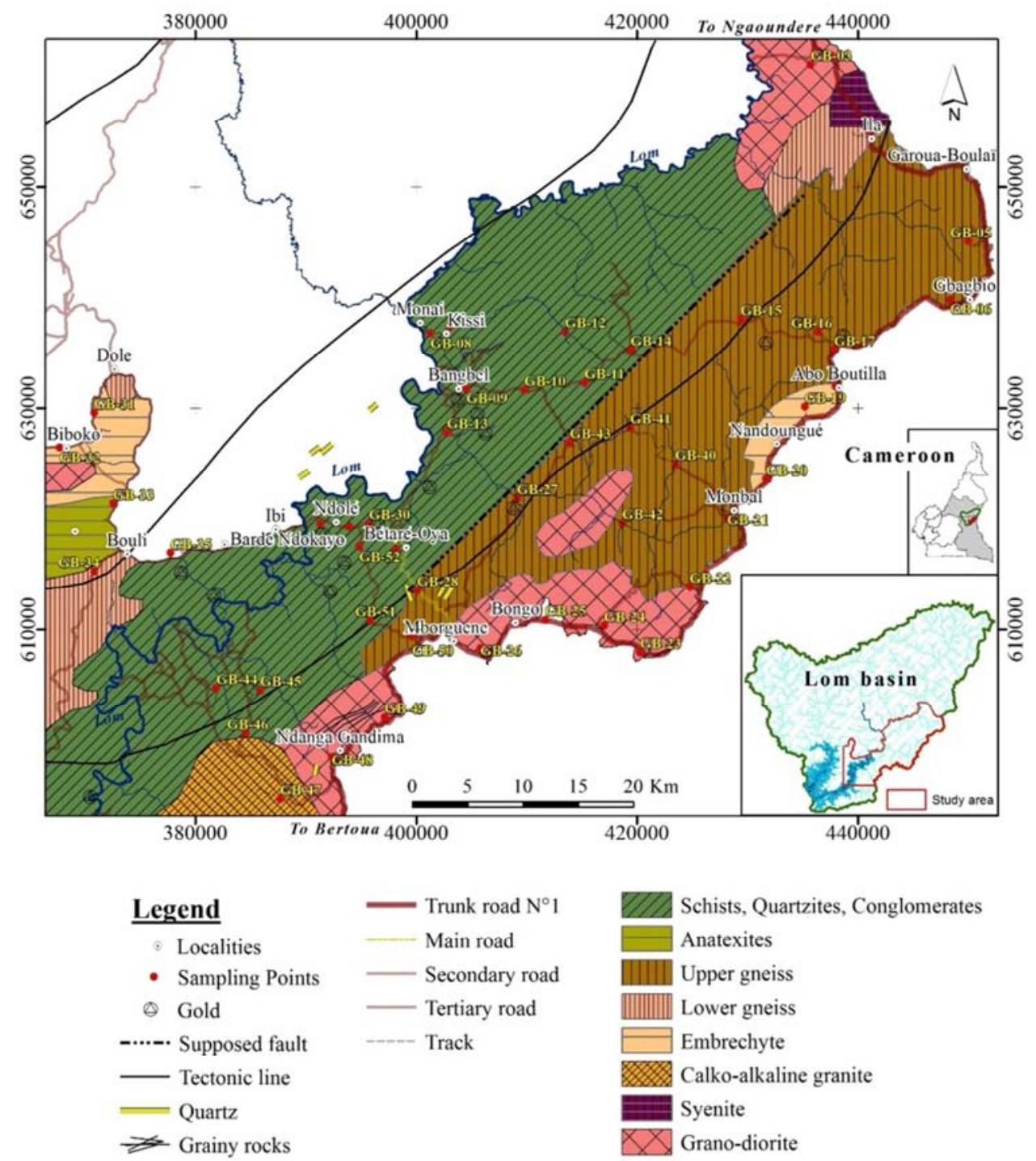

Figure 1. Map of study area showing the location, geology, gold mineralization and sampling points. 
Geologically, the study area is a post-collisional basin, comprising mainly volcaniclastic schists, metasedimentary rocks and the S-type granitoids $[14,8,7]$. The S-type granitic plutons intrude the low-grade metamorphic schists units interpolated with quartzites and metaconglomerates (Figure 1). Uranium- $\mathrm{Pb}$ dating on zircons of the rocks yielded constrained ages of 612-600 Ma implying that sedimentation in the Lom basin occurred after 612 Ma followed by a rapid deformation and low-pressure metamorphism [15-16]. Structures in the Lom Group include trending NE-SW, NNESSW and ENE-WSW faults associated with the Central Cameroon Shear Zone (CCSZ) [8, 7]. The evolution of this pull-apart basin is characterized by the reworking and remobilization of an Archean to Paleoproterozoic basement [16] accounting for its economic potential, especially gold. Gold mineralization in the study area is associated with quartz veins and veinlets, weathering profiles and wall rock alterations. Accordingly, small-scale gold mining has been practiced for over six decades and is on-going [17]. The regional hydrogeochemical baseline defined in this study covers an area of $30000 \mathrm{~km}^{2}$ including the Betare-Oya and Garoua-Boulai gold districts.

\section{Materials and Methods}

\subsection{Sampling Methodology and Sample/Data Treatment}

Systematic sampling of streamwater was carried out at the peak of the dry season in February 2016, covering the southeastern portion of the Lom Basin (Figure 1). During this survey, abandoned and active mine sites were avoided. Field observations such as potential sources of contamination, land use and upstream lithology were documented.

Representative fifty-two streamwater samples were collected from lower order streams $\left(1^{\text {st }}-3^{\text {rd }}\right)$ during low flow conditions following the procedure outlined in the FOREGS (Forum of European Geological Surveys) Geochemical field mapping manual [18]. A sampling density of 1 sample per 5$10 \mathrm{~km}$ was used. The position of each sampling site was marked using a Garmin etrex Global Positioning System. A transparent plastic bucket was filled with streamwater, and the $\mathrm{pH}$, electrical conductivity (EC), total dissolved solids (TDS) and temperature were measured in the field using initially calibrated HI 9811-5 Portable pH/EC/TDS/T meter. The electrodes were rinsed before each measurement with the same water that was sampled and after with distilled water. The meter was calibrated for $\mathrm{pH}$ after every 10 measurements using standard solutions from the manufacturer. At the end of each day, alkalinity was measured in the field using the HACH Digital Titrator model 16900. Two separate sample sets were collected at each site; one was filtered through $0.45 \mu \mathrm{m}$ Millipore membrane filters using $50 \mathrm{ml}$ syringes and stored in previously washed new, narrow-mouth, transparent $50 \mathrm{ml}$ polyethylene bottles. On the same day, $1 \mathrm{ml}$ of $20 \%$ wt. pure concentrated $\mathrm{HNO}_{3}$ was added to the samples. These were used to determine major cations. A second sample set was collected but not acidified and was utilized for the analysis of major anions.

\subsection{Laboratory Analyses}

All chemical analyses were performed at the Laboratory of Volcanology and Geochemistry in Tokai University, Japan. The water samples were analysed for major cations $\left(\mathrm{Ca}^{2+}\right.$, $\mathrm{Mg}^{2+}, \mathrm{Na}^{+}, \mathrm{K}^{+}$) by Flame Atomic Absorption Spectrometer (AAS) and major anions $\left(\mathrm{F}^{-}, \mathrm{Cl}^{-}, \mathrm{NO}_{2}^{-}, \mathrm{NO}_{3}^{-}, \mathrm{Br}^{-}, \mathrm{PO}_{4}{ }^{3-}\right.$, $\mathrm{SO}_{4}{ }^{2-}$ ) by Ion Chromatography (ICS-900). Two replicates were run per sample. Overall, an ionic balance error of $\pm 5 \%$ was considered in further analysis and discussion.

The spatial distribution maps for major ions were compiled using the Inverse Distance Weighting (IDW) technique in ArcGIS10.2 which is based mainly on the distance between the sampling points (5 to $10 \mathrm{~km}$ ). Other information such as geology and land use were used in interpreting element distributions within the basin.

\section{Results and Discussions}

\subsection{Geochemical Data}

Summary statistics for the streamwater data showing physico-chemical parameter measurements and major ion concentrations are presented in table (1). Most streams of the Lom Basin were predominantly neutral to mildly acidic in nature with $\mathrm{pH}$ values between 5.0 and 7.3. Electrical conductivity varied from 9 to $112 \mu \mathrm{S} \mathrm{cm}^{-1}$ and TDS ranged from 4 to $87 \mathrm{mg} / \mathrm{L}$, with an average value of $27.98 \mathrm{mg} / \mathrm{L}$. In agreement with [19] classification, all stream water samples in the study area were categorized as fresh (TDS $<1000 \mathrm{mg}$ /L).

\subsubsection{Major Ion Geochemistry}

Calcium and $\mathrm{Na}^{+}$were the dominant cations followed by $\mathrm{K}^{+}$ and $\mathrm{Mg}^{2+}$. The concentration of $\mathrm{Ca}^{2+}$ varied from 0.2 to 9.48 $\mathrm{mg} / \mathrm{L}$ and accounted for $32 \%$ of the total cations. Concentrations of $\mathrm{Na}^{+}$were higher than those of $\mathrm{Ca}^{2+}$ in $40 \%$ of the analysed water samples. In addition, $\mathrm{Na}^{+}$and $\mathrm{K}^{+}$ contributed $52 \%$ of the total cations. Like $\mathrm{Ca}^{2+}$ and $\mathrm{Na}^{+}$, $\mathrm{HCO}_{3}{ }^{-}$was the dominant anion with a secondary contribution from $\mathrm{NO}_{3}{ }^{-}$. The order of abundance was $\mathrm{HCO}_{3}{ }^{-}>\mathrm{NO}_{3}{ }^{-}>$ $\mathrm{Cl}^{-}>\mathrm{SO}_{4}{ }^{2-}>\mathrm{F}^{-}>\mathrm{NO}_{2}{ }^{-}>\mathrm{Br}^{-}>\mathrm{PO}_{4}{ }^{2-}$. Bicarbonate levels were between 2.73 and $62.66 \mathrm{mg} / \mathrm{L}$ with an average value of $19.41 \mathrm{mg} / \mathrm{L}$ and accounted for $95 \%$ of the total anions. Excess $\mathrm{HCO}_{3}{ }^{-}$can be ascribed to the weathering of aluminosilicate minerals [21-22] or the formation of carbonic acid when $\mathrm{CO}_{2}$ resulting from the decay of organic matter combines with rainwater. The levels of $\mathrm{NO}_{3}{ }^{-}$in the samples were generally low $(<2 \mathrm{mg} / \mathrm{L})$ and constituted $3 \%$ of the total anions. The only exception was sample GB-17 $\left(\mathrm{NO}_{3}{ }^{-}=\right.$ $20.01 \mathrm{mg} / \mathrm{L}$ ) collected from a stream flowing close to an established refugee camp in Gado Badzere. Common sources of dissolved $\mathrm{NO}_{3}{ }^{-}$in water include atmospheric precipitation, domestic sewage, agriculture fertilizers, human and animal 
excrement [23]. The unexpected high $\mathrm{NO}_{3}^{-}$observed suggested the contribution of nitrate by oxidation of human and animal nitrogeneous waste given that open air defecation and cattle farming in this area are practiced on a fairly large scale. Sulphate concentrations $(0.01-0.57 \mathrm{mg} / \mathrm{L})$ were lower than concentrations in natural water $(2-80 \mathrm{mg} / \mathrm{L})[24]$ and reflect the low dissolution sulphide minerals in the near neutral waters. Besides, a negative correlation was observed between $\mathrm{SO}_{4}{ }^{2-}$ and $\mathrm{pH}($ table 2 ) suggesting that the mild acidity recorded in the streams could not have originated through sulphide oxidation but perhaps by pyrite oxidation. Also, it is possible that the acid generated during this process might have been consumed through reactions with silicate minerals thereby providing a long-term buffering capacity [25].

Table 1. Descriptive statistics of physico-chemical parameters of stream water in the study area. Dissolved ion levels are compared to WHO proposed levels.

\begin{tabular}{|c|c|c|c|c|c|c|}
\hline Parameters & Units & Minimum & Maximum & Average & Standard deviation & WHO (2011) \\
\hline Temp & ${ }^{\circ} \mathrm{C}$ & 17.30 & 29.00 & 22.08 & 2.23 & \\
\hline $\mathrm{pH}$ & & 5.00 & 7.30 & 6.26 & 0.47 & $6.50-8.50$ \\
\hline EC & $\mu \mathrm{S} / \mathrm{cm}$ & 9.00 & 112.00 & 36.42 & 30.31 & \\
\hline TDS & $\mathrm{mg} / \mathrm{L}$ & 4.00 & 87.00 & 27.98 & 23.45 & 500.00 \\
\hline $\mathrm{Na}^{+}$ & $\mathrm{mg} / \mathrm{L}$ & 0.06 & 8.96 & 2.34 & 2.13 & 50.00 \\
\hline $\mathrm{K}^{+}$ & $\mathrm{mg} / \mathrm{L}$ & 0.40 & 3.71 & 1.54 & 0.80 & 100.00 \\
\hline $\mathrm{Ca}^{2+}$ & $\mathrm{mg} / \mathrm{L}$ & 0.20 & 9.48 & 2.40 & 2.37 & 75.00 \\
\hline $\mathrm{HCO}_{3}^{-}$ & $\mathrm{mg} / \mathrm{L}$ & 2.73 & 62.66 & 19.41 & 17.29 & 200.00 \\
\hline $\mathrm{NO}_{3}^{-}$ & $\mathrm{mg} / \mathrm{L}$ & 0.01 & 20.01 & 0.75 & 3.23 & 50.00 \\
\hline $\mathrm{Cl}^{-}$ & $\mathrm{mg} / \mathrm{L}$ & 0.07 & 1.28 & 0.23 & 0.21 & 250.00 \\
\hline $\mathrm{SO}_{4}{ }^{2-}$ & $\mathrm{mg} / \mathrm{L}$ & 0.01 & 0.57 & 0.13 & 0.15 & 200.00 \\
\hline $\mathrm{F}^{-}$ & $\mathrm{mg} / \mathrm{L}$ & 0.01 & 0.21 & 0.07 & 0.05 & 1.00 \\
\hline $\mathrm{NO}_{2}^{-}$ & $\mathrm{mg} / \mathrm{L}$ & 0.00 & 0.13 & 0.04 & 0.03 & \\
\hline $\mathrm{Br}^{-}$ & $\mathrm{mg} / \mathrm{L}$ & 0.02 & 0.10 & 0.04 & 0.02 & \\
\hline
\end{tabular}

\subsubsection{Hydrogeochemical Facies of Streams}

The chemical patterns of the streamwater were elucidated by plotting the major ions on a Piper [26] trilinear diagram (Figure 2). This produced two distinctive water types: $77 \%$ of samples plotted as $\mathrm{CaHCO}_{3}$ and $23 \%$ as $\mathrm{NaHCO}_{3}$. These water species are typical of surface water draining igneous/metamorphic rocks in hot and humid equatorial climate, resulting in the discordant dissolution of primary silicate minerals such as Na-feldspars, plagioclases, pyroxene and hornblende [27-28]. Also, the water facies indicate short residence time thus low water-rock interaction [29], ion exchange and active recharge by groundwater associated with low EC [30].

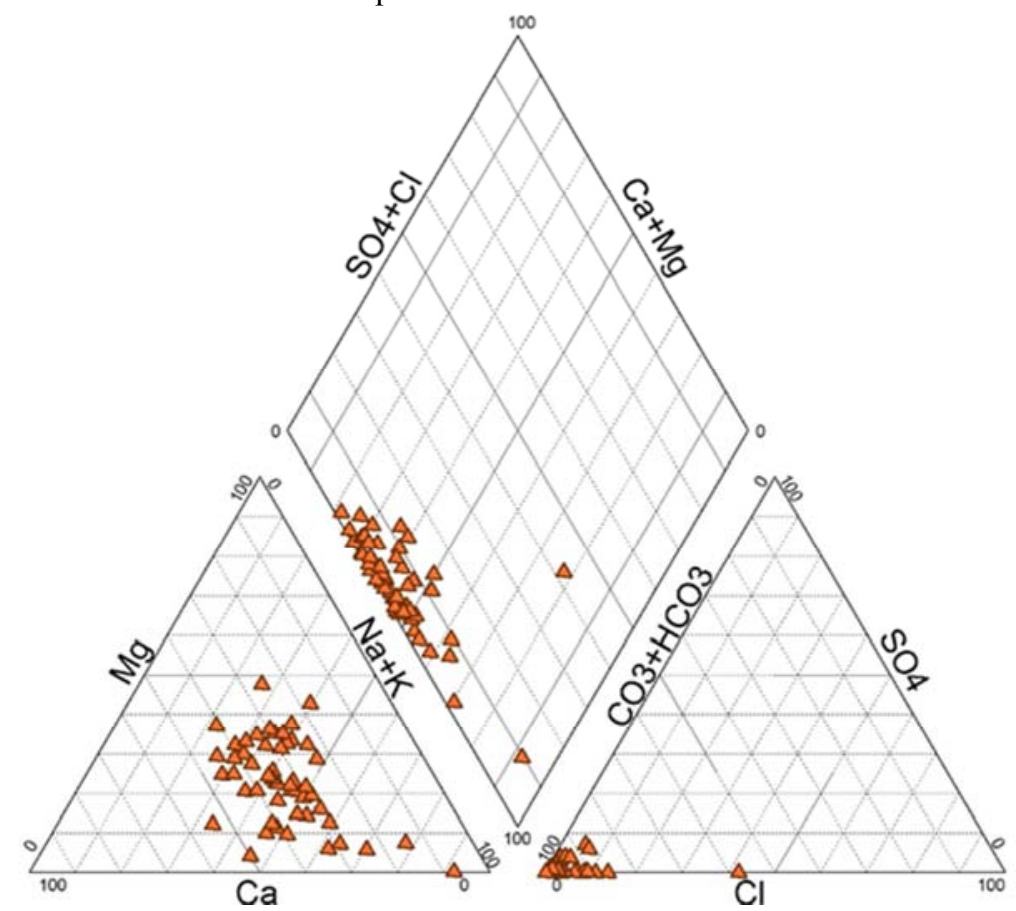

Figure 2. Piper trilinear diagram depicting the chemical species of streamwater in the study area. Streamwater is classified as $\mathrm{Ca}_{-} \mathrm{HCO}_{3}$ and $\mathrm{Na}_{-} \mathrm{HCO} \mathrm{O}_{3}$ water types. 


\subsection{Geochemical Processes Controlling Surface Water Chemistry}

Weathering of silicate and carbonate minerals is a primary source of alkalinity in natural water. Also, the stoichiometric relationships between dissolved species have been used to unravel the origin of solutes and the processes that influenced the observed water chemistry. To investigate the role of mineral weathering, [31] suggested the plot of total cations against alkalinity. Based on this method, a 1:1 relation between the sum of cations and alkalinity is an indication that mineral weathering is the primary process controlling the water chemistry.

In this study, all samples plot on or near the 1:1 dissolution line in Figure $3 \mathrm{a}$ indicating that silicate weathering is the main hydrogeochemical process affecting the surface water chemistry. These common rock-forming minerals are altered by the mildly acidic streamwater through hydrolysis to form metal cations in solution.
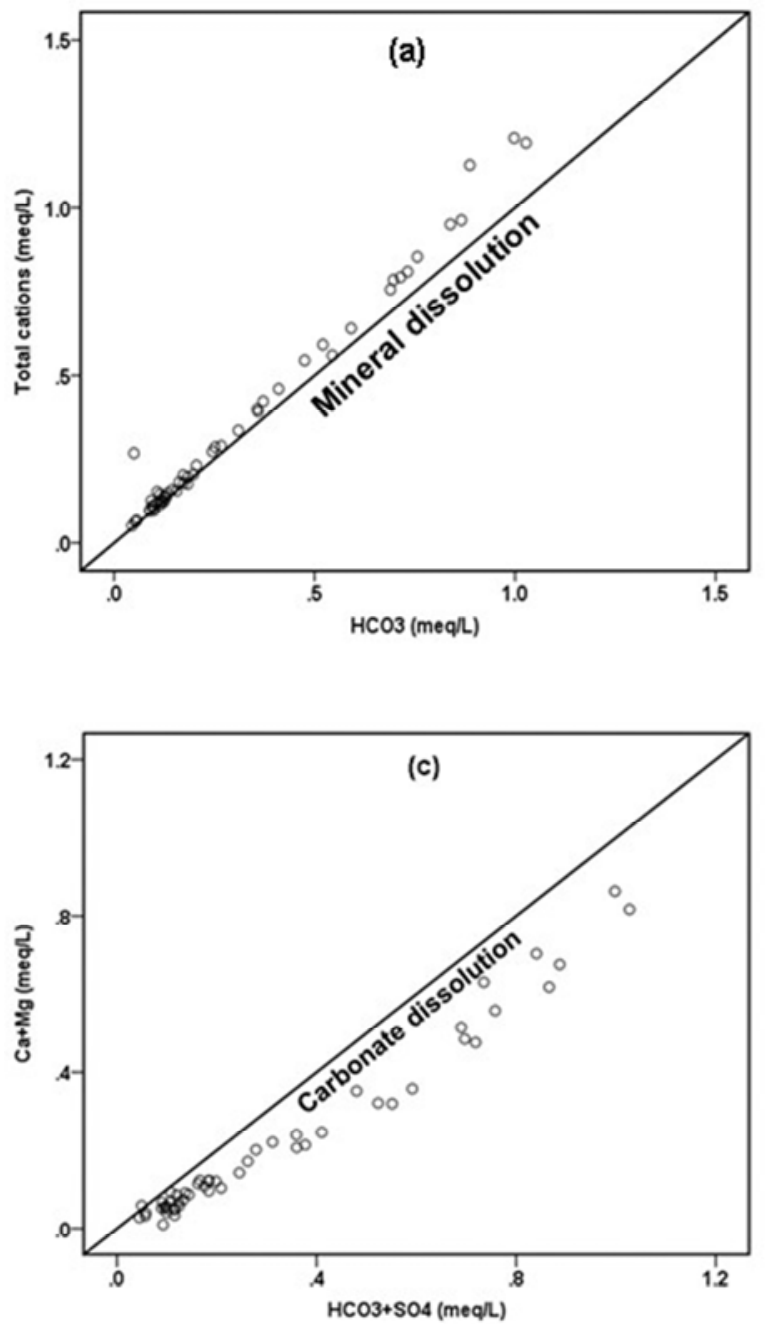

The role of other geochemical processes was investigated using $\mathrm{NO}_{3}^{-}$vs $\mathrm{HCO}_{3}^{-}$plot (Figure 3b). An insignificant negative correlation rules out the possibility of nitrate generating processes given that nitrification or oxidation of organic matter will produce an equivalent of $\mathrm{NO}_{3}{ }^{-}$by consuming the same equivalent of alkalinity [31]. Moreover, [32] proposed that the plot of $\mathrm{Ca}^{2+}+\mathrm{Mg}^{2+}$ against $\mathrm{HCO}_{3}{ }^{-}+\mathrm{SO}_{4}{ }^{2-}$ will be close to the $1: 1$ line when carbonate dissolution is the dominant reaction in the system. However, in this study, all water samples plot below the theoretical equiline with a pronounced deviation at higher concentrations (Figure $3 \mathrm{c}$ ). Higher $\mathrm{HCO}_{3}{ }^{-}+\mathrm{SO}_{4}{ }^{2-}$ content compared to $\mathrm{Ca}^{2+}+\mathrm{Mg}^{2+}$ indicated a significant contribution from non-carbonate sources. Also, the deficiency in the sum of alkaline earth metals relative to bicarbonate requires that the excess negative charge of the anions be balanced by $\mathrm{Na}^{+}+\mathrm{K}^{+}$supplied through the weathering of Na-K silicates [33].
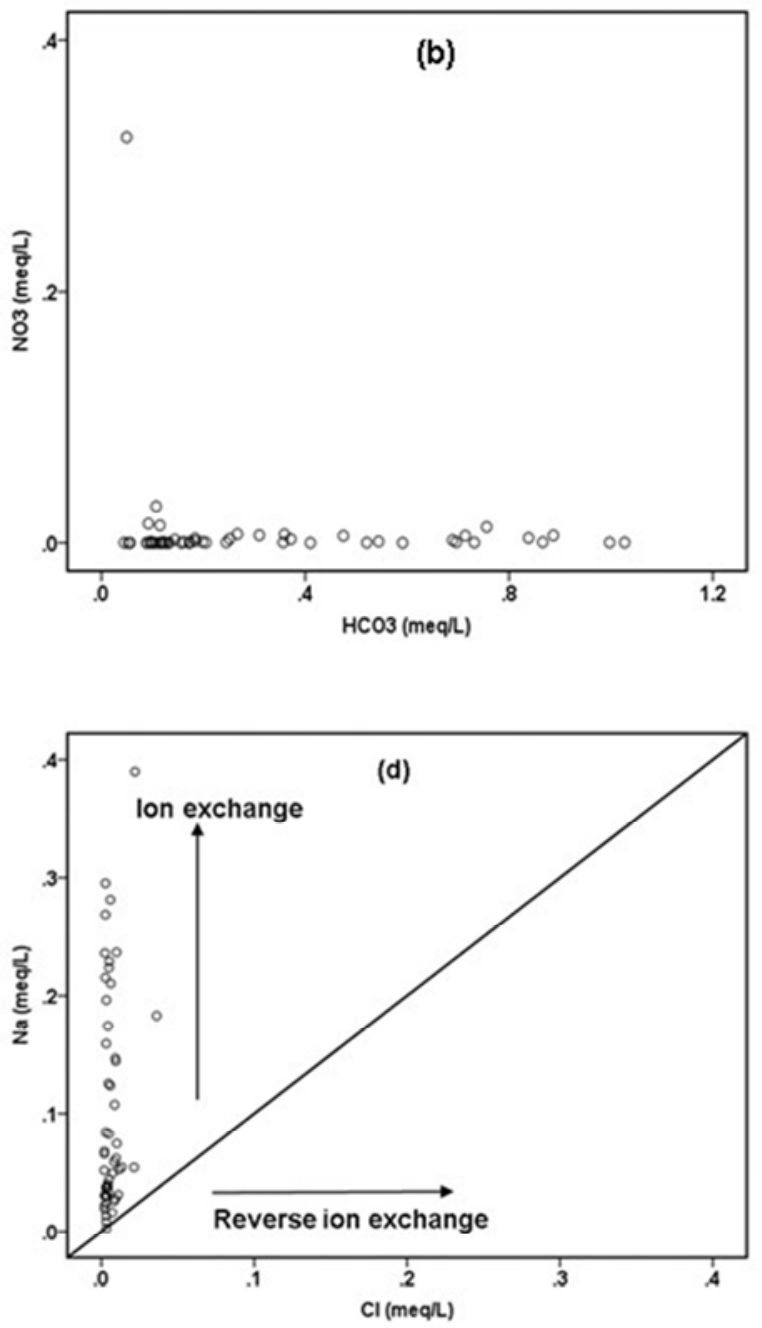

Figure 3. Mechanisms governing streamwater chemistry. (a) Relation between total cations and alkalinity showing silicate weathering (b) Variation in $\mathrm{NO}_{3}$ concentrations as a function of alkalinity (c) Relation between $\mathrm{Ca}^{2+}+\mathrm{Mg}^{2+}$ and $\mathrm{HCO}_{3}^{-}+\mathrm{SO}_{4}{ }^{2-}$ showing non-carbonate dissolution (d) $\mathrm{Na}$ vs. Cl cross plot. Sodium is derived from cation exchange. 
The relationship between $\mathrm{Na}$ and $\mathrm{Cl}$ is frequently used to determine the source of salinity in natural waters. Besides, the stoichiometry of halite dissolution demands equal concentrations of $\mathrm{Na}^{+}$and $\mathrm{Cl}^{-}$in solution and corresponding molar ratio of approximately one [33]. The molar ratio of $\mathrm{Na}^{+} / \mathrm{Cl}^{-}$in the water samples compared to seawater $(0.86)$ varied from 0.81 to 111.58 (average 23.2) with $98 \%$ of the samples showing $\mathrm{Na}$ enrichment. Higher $\mathrm{Na}^{+} / \mathrm{Cl}^{-}$ratios $(>1)$ reflect contributions from non-halite sources. From the 1:1 plot of $\mathrm{Na}^{+}$against $\mathrm{Cl}^{-}$(Figure 3d), an increase in $\mathrm{Na}^{+}$ without a corresponding increase in $\mathrm{Cl}^{-}$was observed. This can be attributed to the possible exchange of $\mathrm{Ca}^{2+}$ for $\mathrm{Na}^{+}$at clay surfaces or organic components of the soil resulting in the $\mathrm{Na}-\mathrm{HCO}_{3}$ water type. Organic matter and clay minerals have negatively charged ions which can adsorb and hold positively charged base cations by electrostatic force.

Furthermore, Pearson's correlation matrix (table 2) was computed to determine the inter-element relationship. From the resultant matrix, $\mathrm{pH}$ revealed a negative correlation with most of the variables. The electrical conductivity showed a high correlation $(r=0.923)$ with TDS indicating its direct relationship to the amount of dissolved salts in water. Similarly, high positive $r$ values were observed between $\mathrm{HCO}_{3}{ }^{-}$and the major cations. Chloride showed relatively high (0.84) and moderate (0.402) correlations with $\mathrm{NO}_{3}^{-}$and $\mathrm{SO}_{4}{ }^{2-}$, respectively. The underlying geochemical processes controlling the composition of stream water in the Lom Basin were investigated following principal component analysis (PCA) computation (table 3). Varimax rotation was adopted.
In PCA, eigenvalues are commonly used to identify the number of components (PCs) that can be retained for later study [34]. Only PCs with eigenvalues greater than unity were extracted for further analysis. Thus, three PCs were considered which accounted for $83.7 \%$ of the total variance of information of the dataset. Principal component 1 (PC1) comprised TDS-EC- $\mathrm{HCO}_{3}{ }^{-}-\mathrm{Mg}^{2+}-\mathrm{Ca}^{2+}-\mathrm{Na}^{+}-\mathrm{K}^{+}-\mathrm{pH}$ and explained $59.7 \%$ of the total variance. The strong positive loading $(>0.9)$ observed in this component suggested a common source, essentially the weathering of silicate minerals, and to some extent cation exchange. Carbonic acid facilitates the breakdown of silicate minerals. This reaction is accompanied by the release of base cations, silic acid and increased alkalinity [35] as observed in the study area. Potassium showed a moderate loading (0.652) suggesting $\mathrm{K}^{+}$ was removed from solution by clays in the formation of secondary minerals.

PC2 constituted $\mathrm{Cl}^{-}$and $\mathrm{NO}_{3}{ }^{-}$which explained $14.2 \%$ of the total variance. A negative contribution from the other variables was also observed. The combination of these anions indicated their anthropogenic input through human-related activities such as sewage sludge and cattle rearing in the surrounding communities [29]. The third component composed of $\mathrm{SO}_{4}{ }^{2-}$ and accounted for $9.8 \%$ of the total variance. This single variable correlated with the presence of sulphide bearing minerals and gold deposits. Gold occurs as quartz veins associated with vug-filling early pyritization in the Lom Basin [9].

Table 2. Pearson's correlation matrix of measured water quality parameters.

\begin{tabular}{|c|c|c|c|c|c|c|c|c|c|c|c|}
\hline & pH & EC & TDS & $\mathrm{Cl}^{-}$ & $\mathrm{SO}_{4}{ }^{2-}$ & $\mathrm{NO}_{3}^{-}$ & $\mathrm{HCO}_{3}{ }^{-}$ & $\mathbf{N a}^{+}$ & $\mathbf{K}^{+}$ & $\mathrm{Ca}^{2+}$ & $\mathbf{M g}^{2+}$ \\
\hline $\mathrm{pH}$ & 1 & & & & & & & & & & \\
\hline EC & $0.395^{* *}$ & 1 & & & & & & & & & \\
\hline TDS & $0.381^{* *}$ & $0.923^{* *}$ & 1 & & & & & & & & \\
\hline $\mathrm{Cl}^{-}$ & -0.007 & 0.234 & 0.264 & 1 & & & & & & & \\
\hline $\mathrm{SO}_{4}{ }^{2-}$ & -.0004 & -0.109 & -.137 & $0.402^{* *}$ & 1 & & & & & & \\
\hline $\mathrm{NO}_{3}^{-}$ & -0.081 & 0.162 & 0.219 & $0.840^{* *}$ & $0.491^{* *}$ & 1 & & & & & \\
\hline $\mathrm{HCO}_{3}^{-}$ & 0.004 & 0.028 & 0.002 & 0.170 & $0.986^{* *}$ & 0.107 & 1 & & & & \\
\hline $\mathrm{Na}^{+}$ & -0.022 & -0.078 & -0.107 & 0.401 & $0.999^{* *}$ & $0.356^{*}$ & $0.990^{* *}$ & 1 & & & \\
\hline $\mathrm{K}^{+}$ & -0.092 & -0.040 & -0.106 & 0.177 & $0.934^{* *}$ & 0.150 & $0.965^{* *}$ & $0.948^{* *}$ & 1 & & \\
\hline $\mathrm{Ca}^{2+}$ & $0.357^{* *}$ & $0.965^{* *}$ & $0.961^{* *}$ & 0.198 & 0.167 & 0.177 & $0.967^{* *}$ & $0.866^{* *}$ & $0.729^{* *}$ & 1 & \\
\hline $\mathrm{Mg}^{2+}$ & $0.313^{*}$ & $0.978^{* *}$ & $0.970^{* *}$ & 0.219 & 0.157 & 0.139 & $0.978^{* *}$ & $0.908^{* *}$ & $0.705^{* *}$ & $0.938^{* *}$ & 1 \\
\hline
\end{tabular}

** correlation is significant at the 0.01 level (2-tailed).

* correlation is significant at the 0.05 level (2-tailed).

\subsection{Regional Spatial Distribution and Sources of Enriched Geochemistry}

The regional geochemical maps for dissolved ions are presented in figures 4 to 12 . Concentrations of $\mathrm{Cl}^{-}$and $\mathrm{NO}_{3}{ }^{-}$ (Figures 4 and 5) corresponded to high levels of $\mathrm{H}^{+}$or low $\mathrm{pH}$ (Figure 6) in the northeastern portion of the study area which involves localities close to the volatile border between Cameroon and the Central African Republic. These localities host more than two hundred thousand refugees. Hence, the domestic waste water produced from these municipalities, stock-raising and open air defecation contributed to $\mathrm{NO}_{3}{ }^{-}$and $\mathrm{Cl}^{-}$concentrations and account for the mild acidity recorded in water. Bicarbonate, $\mathrm{Ca}^{2+}, \mathrm{Na}^{+}, \mathrm{K}^{+}$, and $\mathrm{Mg}^{2+}$ showed similar distribution trends (Figures 7-11) basically indicating the underlying geology of the catchment area. These cations form the common silicate minerals alongside silicon and oxygen. Also, the incongruent dissolution of silicate minerals that react with dissolved $\mathrm{CO}_{2}$ gas derived directly from the atmosphere, decay of organic matter in the soil or photosynthesis results in the release of major cations, bicarbonate and dissolved silica [36]. 
Table 3. Varimax rotated component matrix analysis of streamwater parameters.

\begin{tabular}{lllll}
\hline Variable & Component 1 & Component 2 & Component 3 & Communalities \\
\hline $\mathrm{TDS}$ & 0.997 & -0.002 & 0.022 & 0.552 \\
$\mathrm{EC}$ & 0.995 & 0.033 & 0.001 & 0.992 \\
$\mathrm{HCO}_{3}{ }^{-}$ & 0.994 & -0.035 & 0.019 & 0.994 \\
$\mathrm{Mg}^{2+}$ & 0.955 & 0.048 & -0.037 & 0.837 \\
$\mathrm{Ca}^{2+}$ & 0.954 & -0.080 & -0.015 & 0.634 \\
$\mathrm{Na}^{+}$ & 0.944 & 0.124 & -0.024 & 0.939 \\
$\mathrm{~K}^{+}$ & 0.652 & -0.026 & 0.320 & 0.990 \\
$\mathrm{Ph}$ & 0.609 & -0.340 & 0.255 & 0.907 \\
$\mathrm{Cl}^{-}$ & 0.196 & 0.890 & 0.075 & 0.528 \\
$\mathrm{NO}_{3}^{-}$ & -0.142 & 0.780 & -0.077 & 0.917 \\
$\mathrm{SO}_{4}{ }^{-2}$ & -0.011 & -0.010 & 0.969 & 0.916 \\
Eigen values & 6.541 & 1.543 & 1.121 & \\
\% Variance & 59.466 & 14.202 & 9.803 & \\
Cumulative\% & 59.466 & 73.896 & 83.687 & \\
\hline
\end{tabular}

Comparable findings have been reported in some natural waters of Cameroon [21, 37-38, 27]. These authors attributed the solute composition of natural waters to the hydrolysis of the rock-forming minerals and the incongruent weathering reactions. Contrary to the major cations, the distribution of $\mathrm{SO}_{4}{ }^{2-}$ (Figure 12) correlated with the occurrence of sulphide minerals associated with $\mathrm{Au}$ mineralization in the area. Sulphidation of the wall rock has been proposed as a possible mechanism of hypogene gold precipitation within the Lom Group [9].

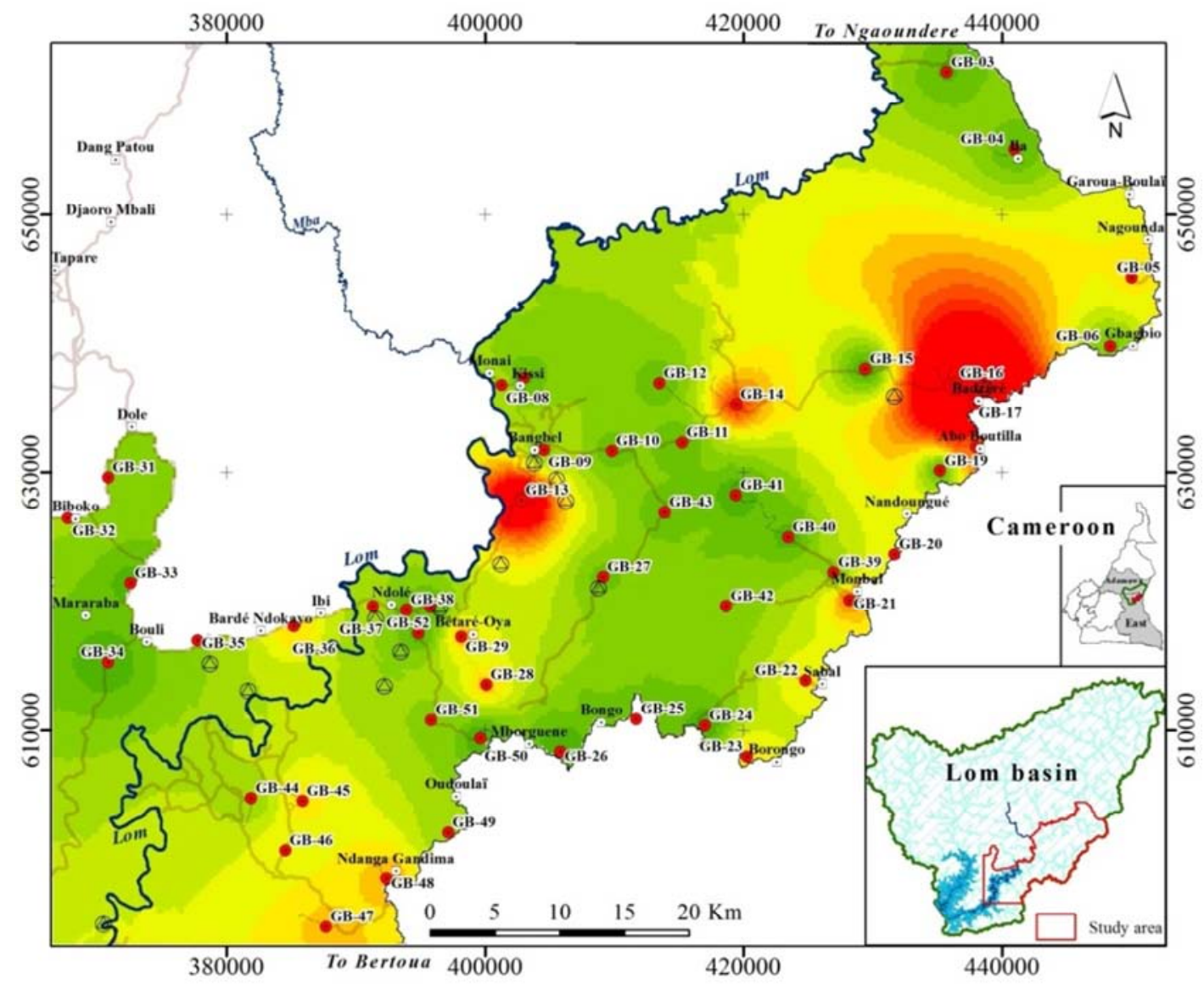

\section{Legend}

- Sampling Points

¿ Localities

(4) Gold

$\sim$ Water Body
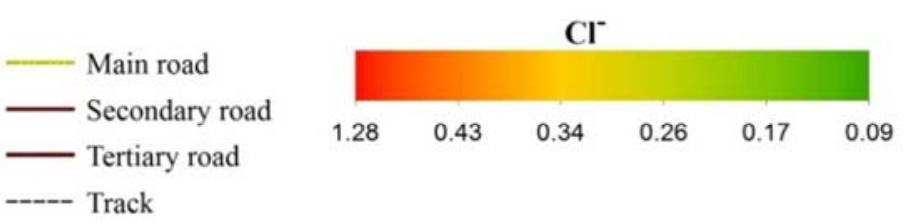

Figure 4. Streamwater regional geochemical baseline map of $\mathrm{Cl}$ concentration in southeastern Lom Basin. Dissolved ion concentrations are in mg/L. 


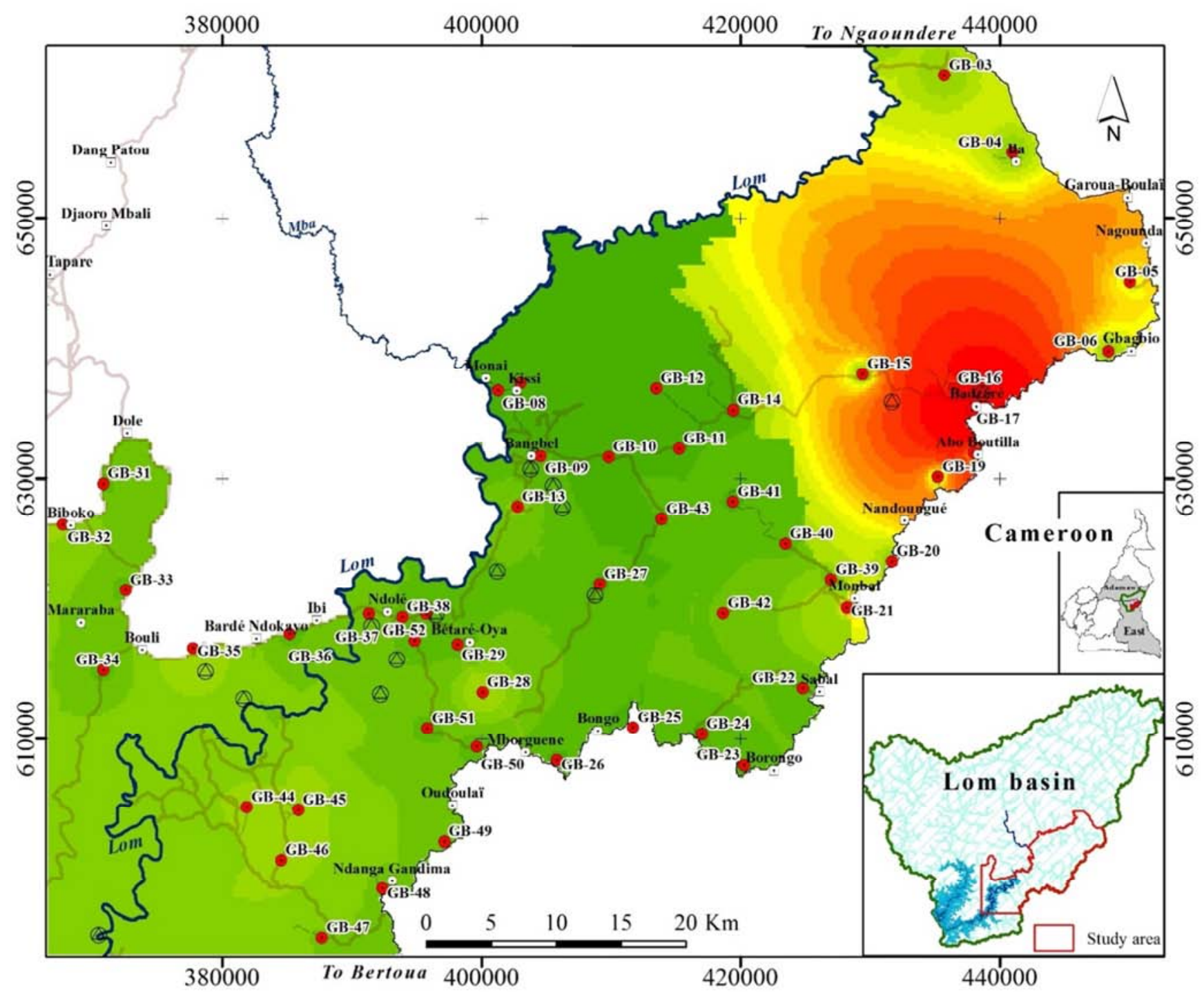

Legend
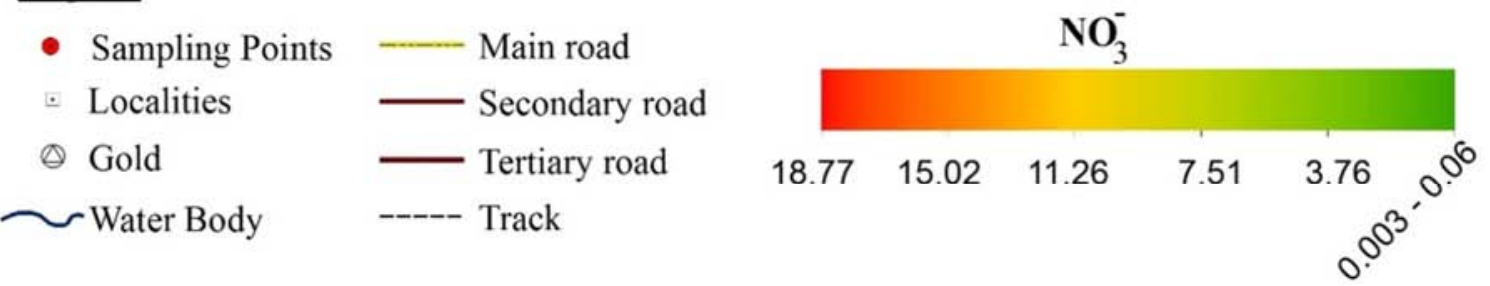

Figure 5. Streamwater regional geochemical baseline map of $\mathrm{NO}_{3}^{-}$concentration in southeastern Lom Basin. Dissolved ion concentrations are in mg/L. 


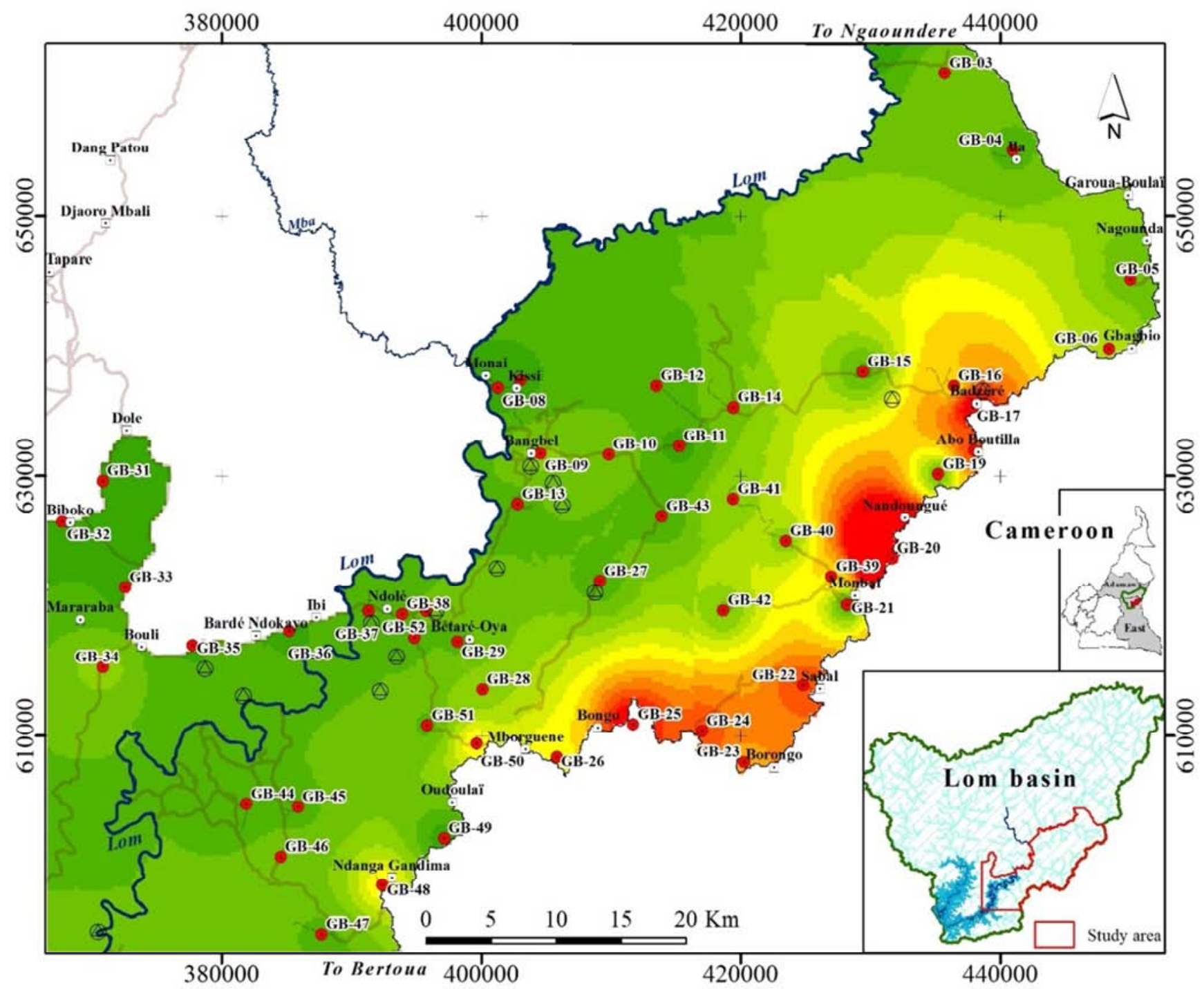

Legend

- Sampling Points

_- Main road

¿ Localities

— Secondary road

( ) Gold

Tertiary road

$\sim$ Water Body

----- Track

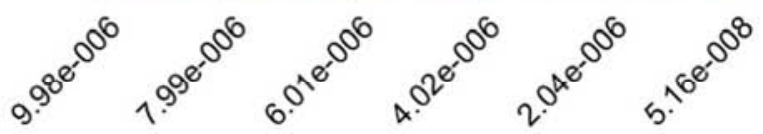

Figure 6. Streamwater regional geochemical baseline map of $H^{+}$concentration in southeastern Lom Basin. Dissolved ion concentrations are in mg/L. 


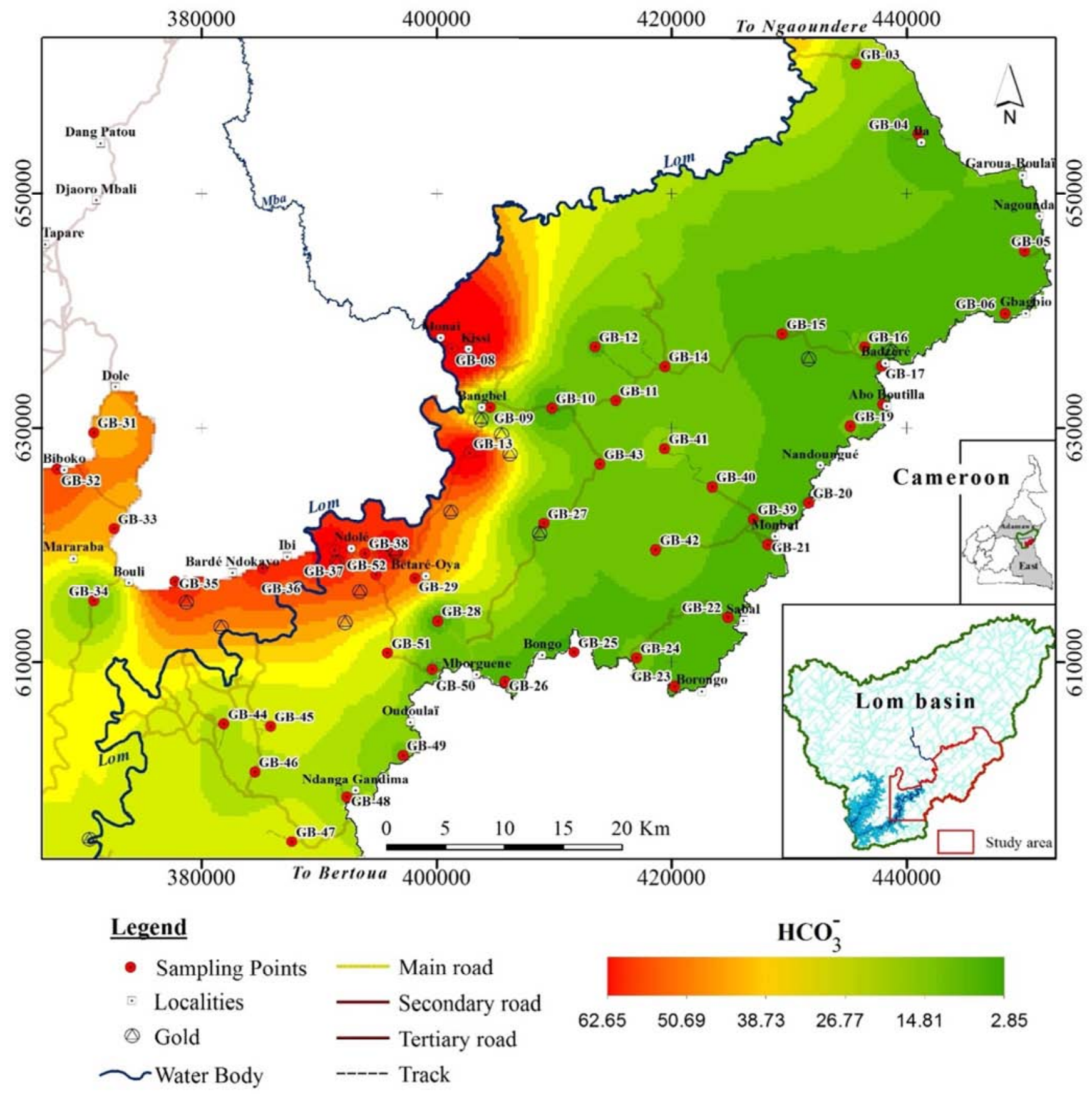

Figure 7. Streamwater regional geochemical baseline map of $\mathrm{HCO}_{3}^{-}$in southeastern Lom Basin. Dissolved ion concentrations are in mg/L. 


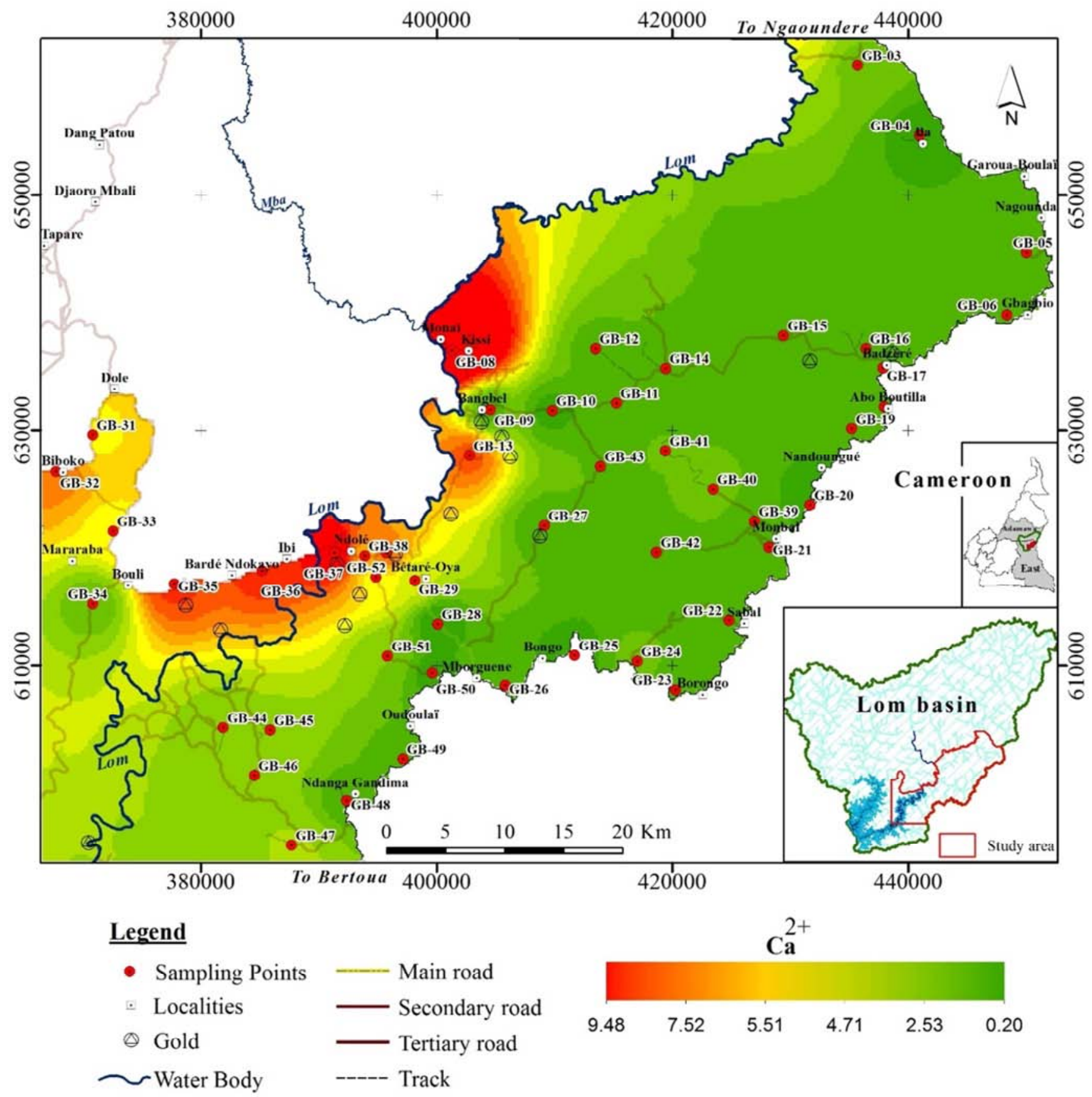

Figure 8. Streamwater regional geochemical baseline map of $\mathrm{Ca}^{2+}$ in southeastern Lom Basin. Dissolved ion concentrations are in mg/L. 


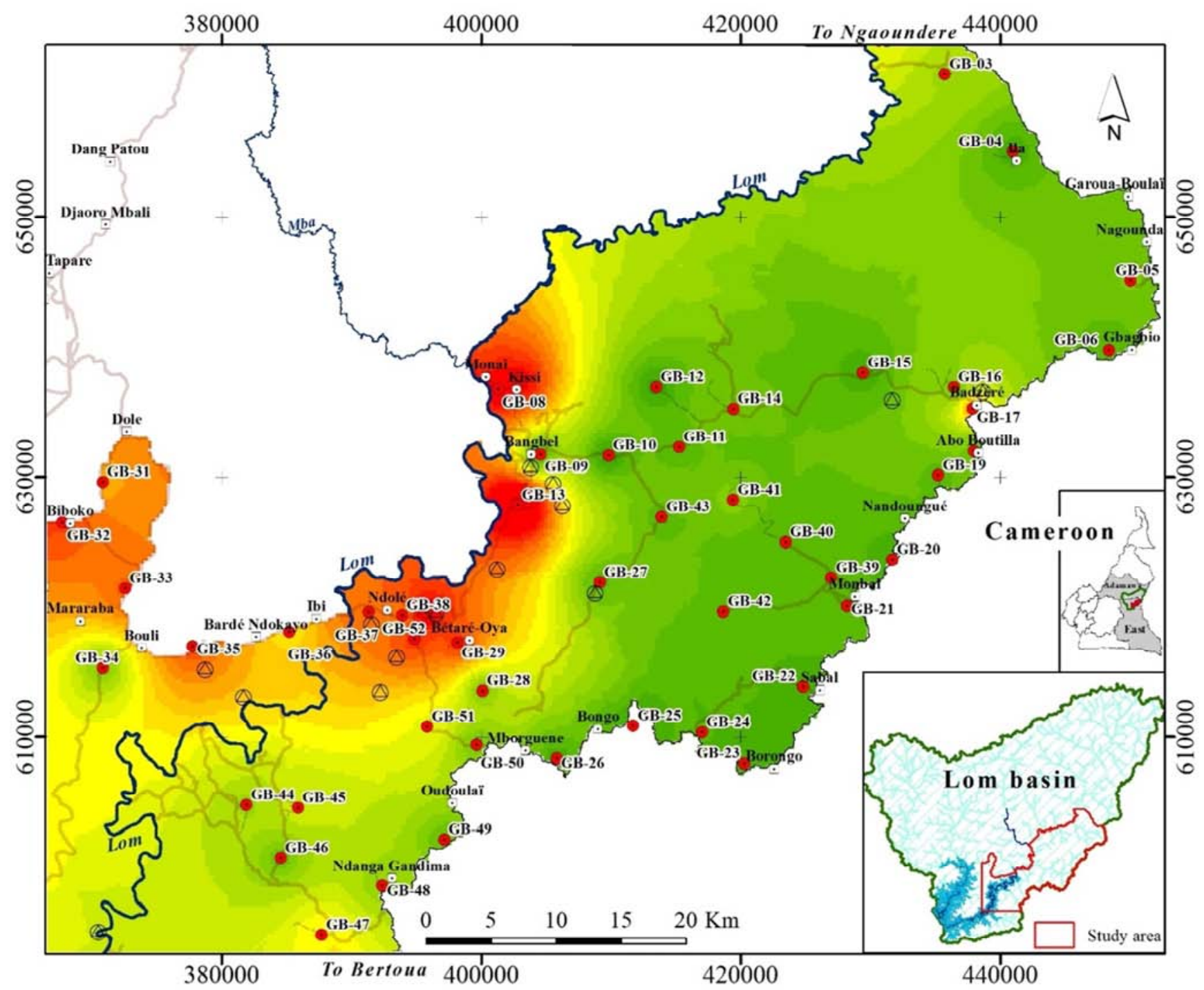

Legend

- Sampling Points

¿ Localities

Main road

(- Gold

- Secondary road

- Tertiary road

----- Track

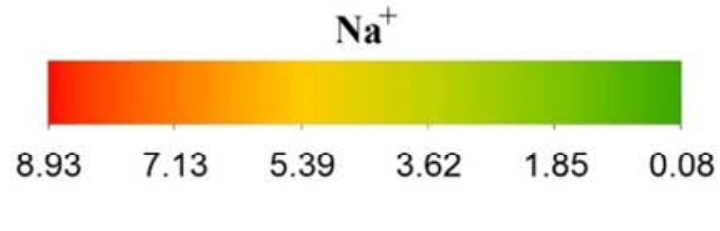

Figure 9. Streamwater regional geochemical baseline map of $\mathrm{Na}^{+}$in southeastern Lom Basin. Dissolved ion concentrations are in $\mathrm{mg} / \mathrm{L}$. 


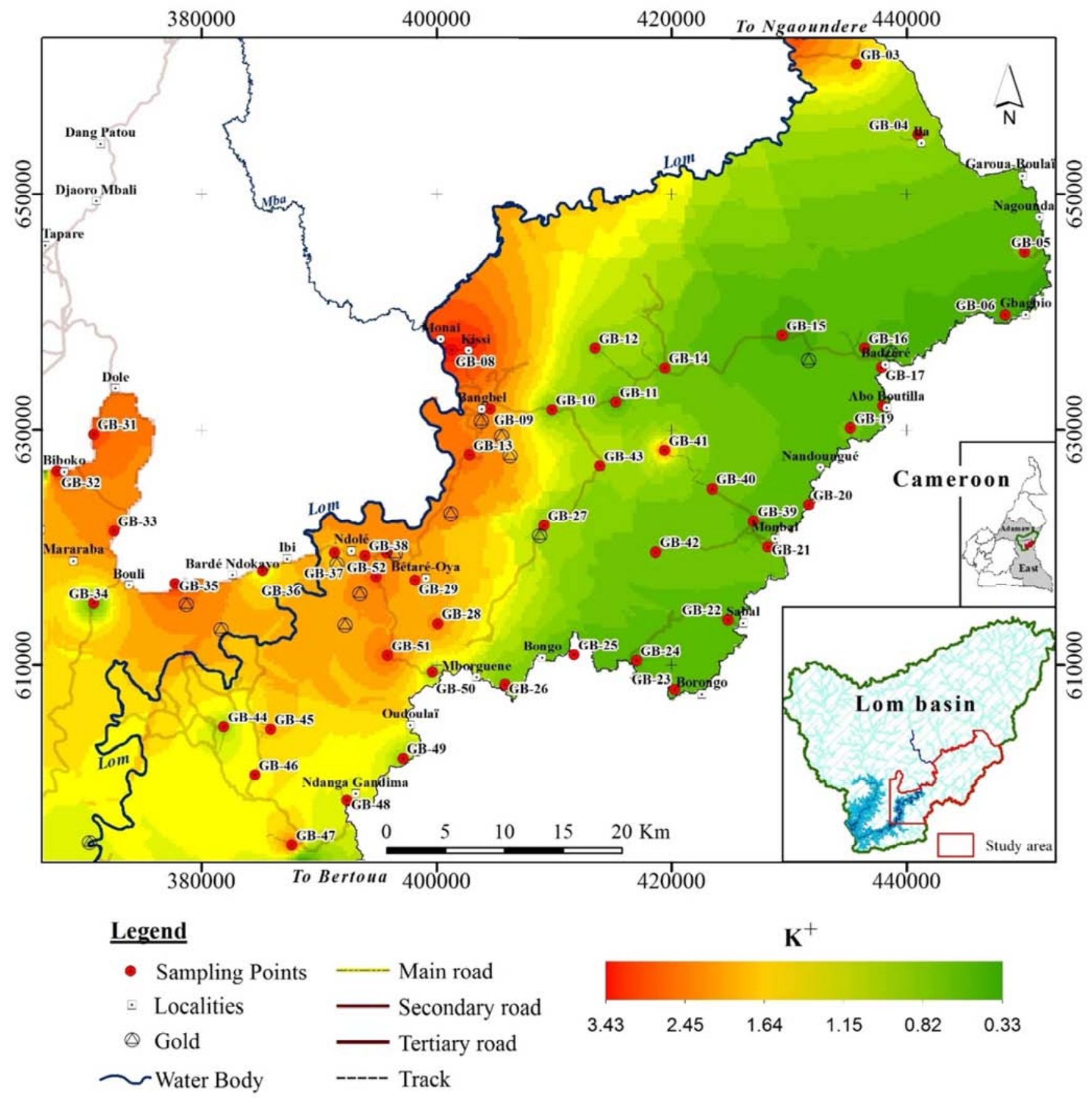

Figure 10. Streamwater regional geochemical baseline map of $K^{+}$in southeastern Lom Basin. Dissolved ion concentrations are in $m g / L$. 


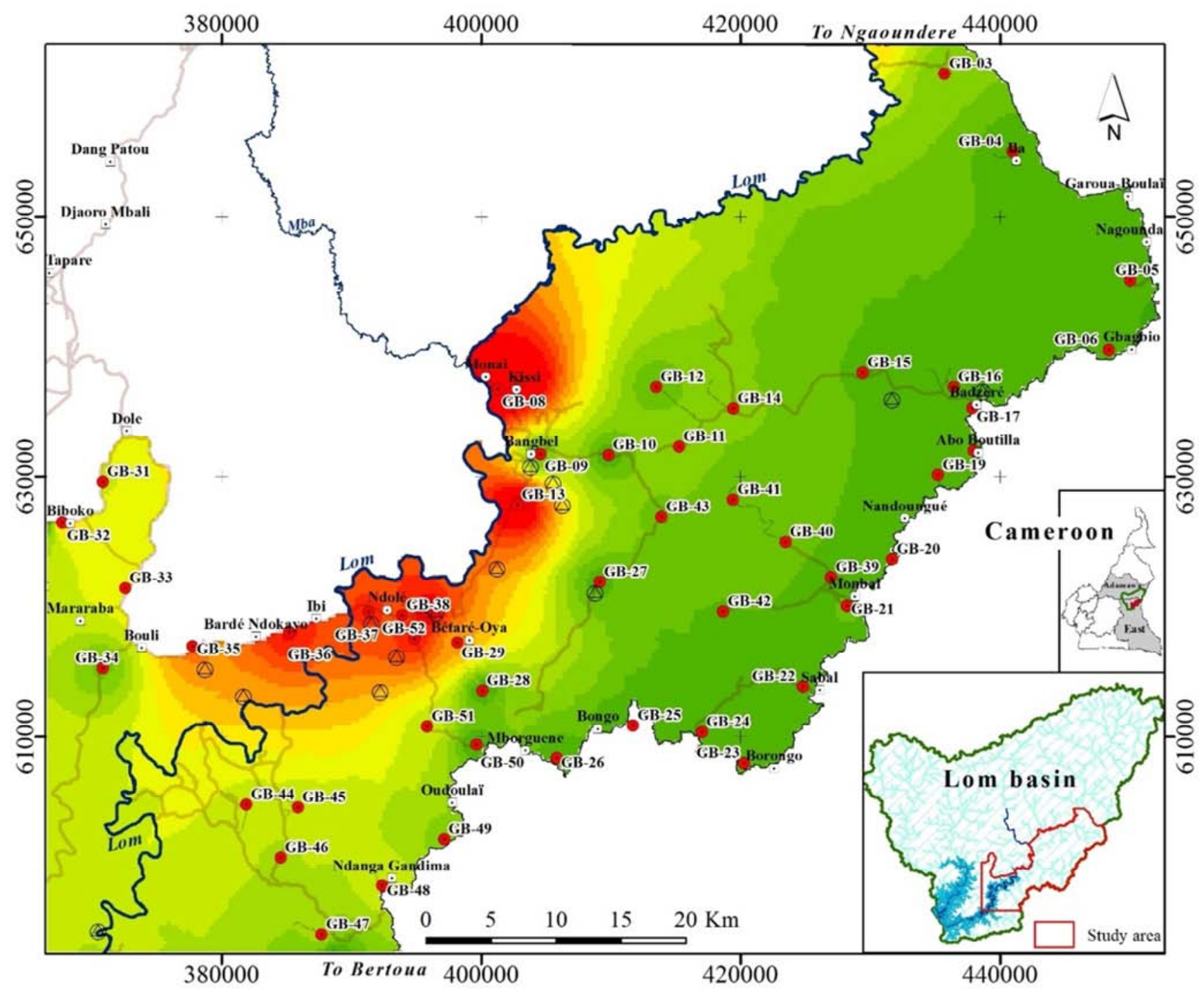

\section{Legend}

- Sampling Points

- Localities

(4) Gold

$\sim$ Water Body
- Main road

- Secondary road

- Tertiary road ----- Track

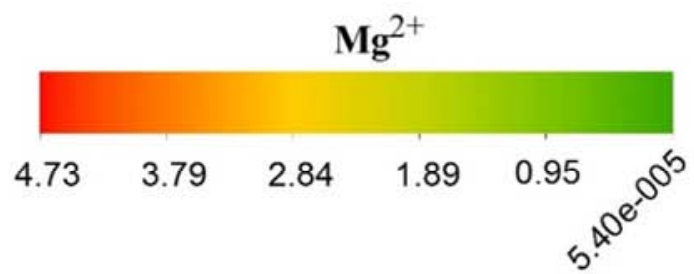

Figure 11. Streamwater regional geochemical baseline map of $\mathrm{Mg}^{2+}$ in southeastern Lom Basin. Dissolved ion concentrations are in mg/L. 


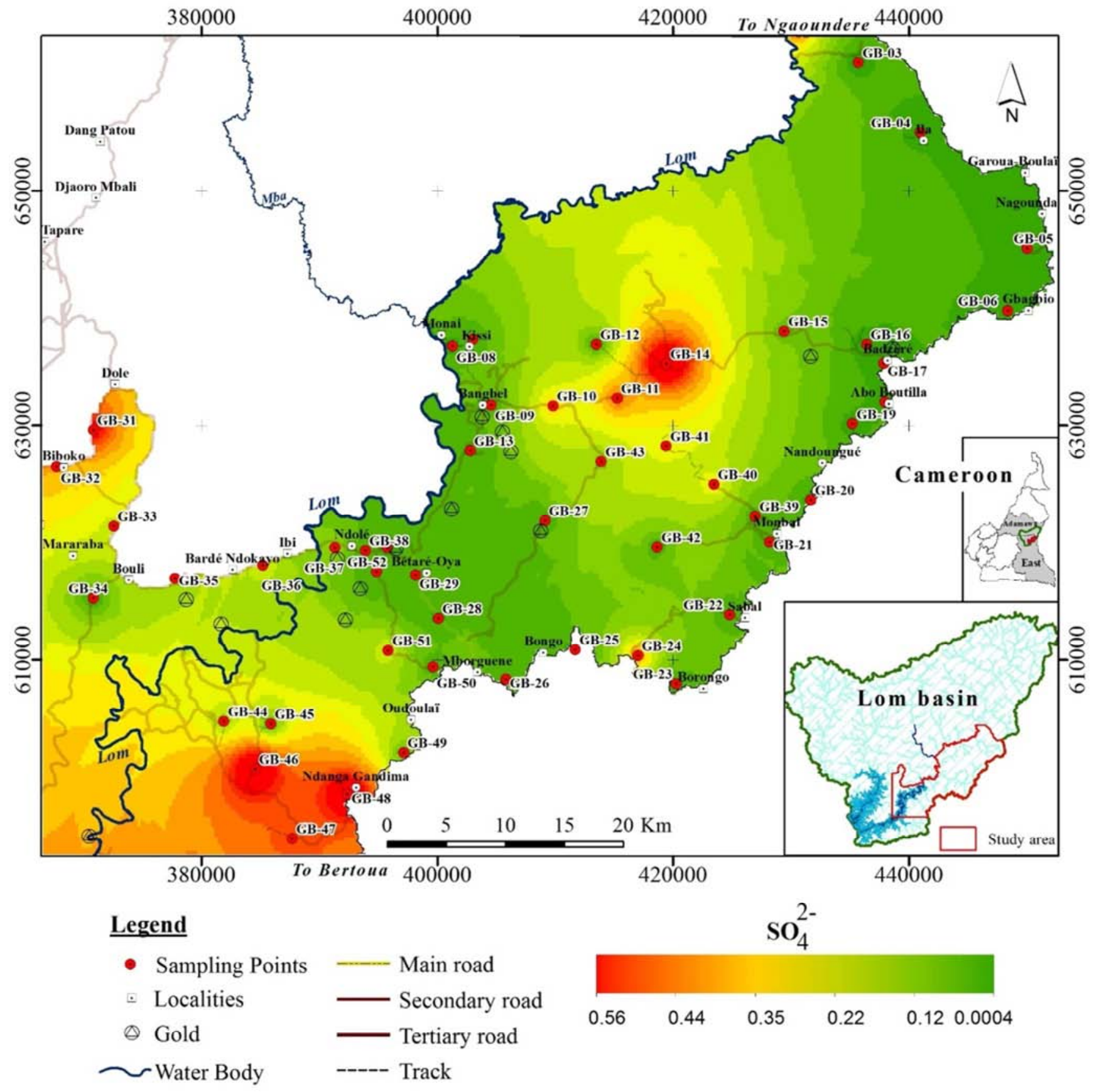

Figure 12. Streamwater regional geochemical baseline map of $\mathrm{SO}_{4}{ }^{2-}$ in southeastern Lom Basin. Dissolved ion concentrations are in $\mathrm{mg} / \mathrm{L}$.

\section{Conclusions}

This study assessed the hydrochemistry of streamwater in the Lom catchment. The streamwater is mildly acidic to neutral in nature. Calcium and $\mathrm{Na}^{+}$were the dominant cations and $\mathrm{HCO}_{3}^{-}$was the most abundant anion. All the analysed parameters except $\mathrm{pH}$ were within the desirable limits (WHO) for drinking purposes. $\mathrm{CaHCO}_{3}$ and $\mathrm{NaHCO}_{3}$ were the main water types in the area signifying freshwater. In this research, the interrelationship among dissolved species have been used to determine the roles of different geochemical processes affecting the chemistry of streams draining the Lom Basin. Accordingly, the observed chemical composition of the streamwater was mostly influenced by the chemical weathering of the surrounding rocks. Cation exchange and anthropogenic activities were identified as minor geochemical controls.

The provenance of elements was distinguished based on geology and land use. Bicarbonate, $\mathrm{Na}^{+}, \mathrm{Ca}^{2+}, \mathrm{Mg}^{2+}$ and $\mathrm{K}^{+}$ showed similar distribution trends reflecting the geology. Sulphate distribution correlated with the occurrence of sulphides associated with vein gold deposits in the area. The distribution patterns of $\mathrm{NO}_{3}^{-}$and $\mathrm{Cl}^{-}$were attributed to pollution from settlements. These dissolved ions were considered to influence the acidity locally. The quality of surface water is easily influenced by anthropogenic activities, 
and stream sediment collects effectively trace metals resulting from such activities. Therefore, geochemical mapping incorporating surface water and stream sediment is of considerable value in future investigations within the Lom Basin.

\section{Acknowledgements}

This article forms part of Ph. D. research of MEM at Tokai University supported through the Japanese Government (MONBUKAGAKUSHO) Scholarship scheme under the Ministry of Education, Culture, Sports, Science and Technology (MEXT). Funding of the project by the Japan Science and Technology Agency (JST) is sincerely acknowledged. The authors are grateful for the provision of transportation facilities by the Institute of Geological and Mining Research (IRGM), Cameroon. Ivo Sumbele is thanked for his diligent assistance during the field survey.

\section{References}

[1] Howarth, R. J., Thornton, I. 1983. Regional geochemical mapping and its application to environmental studies. Appl. Environ. Geochem (Thornton, I., ed.), pp. 14-73, Academic Press

[2] Lapworth, D. J., Knights, K. V., Key, R. M., Johnson, C. C., Ayoade, E., 2012. Geochemical mapping using stream sediments in west-central Nigeria: Implications for environmental studies and mineral exploration in West Africa. Appl. Geochem. Vol. 7, pp. 1035-1052.

[3] Ibe, K. K., Akaolisa, C. Z. 2010. Hydrogeochemical data as a tool for exploration and mapping: a case study from part of Afikpo Basin southeastern Nigeria. Environ. Monit. Assess. Vol. 160, pp. 393-400.

[4] Gray, D. J., Noble, R. R. P., Reid, N., Sutton, G. J., Pirlo, M. C. 2016. Regional scale hydrogeochemical mapping of the northern Yilgarn Craton, Western Australia: a new technology for exploration in arid Australia. Geochem: Explor. Environ. Analy. Vol. 16, pp. 100-115.

[5] Kelepertzis, E., Argyraki, A., Daftsis, E. 2012. Geochemical signature of surface and stream sediments of a mineralized drainage basin at NE Chalkidiki Greece: A pre-mining survey. J. Geochem. Explor. Vol. 114, pp. 70-81.

[6] Freyssinet, P. H., Lecompte, P., Edimo, A. 1989. Dispersion of gold base metals in the Mborguene lateritic profile, East Cameroon. J. Geochem. Explor. Vol. 32, pp. 99-116.

[7] Ngako, V., Affaton, P., Nnange, J. M., Njanko, T. H. 2003. PanAfrican tectonic evolution in central and southern Cameroon: transpression and transtension during sinistral shear movements. J. African Earth Sciences. Vol. 36, pp. 207-221.

[8] Toteu, S. F., Van Schmus, R. W., Penaye, J., Michard, A. 2001. New U-P b and Sm-Nd data from north central Cameroon and its bearing on the pre-pan-African history of Central Africa. Precam. Res. Vol. 108, pp. 45-73.

[9] Omang, B. O., Bih, C. V., Fon, N. N., Suh, C. E. 2014. Regional geochemical stream sediment survey for gold exploration in the upper Lom basin, eastern Cameroon. Int. J.
Geosciences. Vol. 5, pp. 1012-1026.

[10] Jorquera, C O., Oates, C. J., Plan, J. A., Kyser, K., Ihenfield, C., Vouvoulis, N. 2015. Regional hydrogeochemical mapping in Central Chile: natural and anthropogenic sources of elements and compounds. Geochem: Explor. Environ. Analy. Vol. 15, pp. 72-96.

[11] Salminen, R., Gregorauskiene, V. 2000. Considerations regarding the definition of a geochemical baseline of elements in the surficial materials in areas differing in basic geology. Appl. Geochem. Vol. 15, pp. 647-653.

[12] Reimann, C., Garrett, R. G. 2005. Geochemical backgroundconcept and reality. Sci. Total Environ. Vol. 350, pp. 12-27.

[13] Plant, J. A., Smith, D., Smith, B., Williams, L. 2001. Environmental geochemistry at global scale. Appl. Geochem. Vol. 16, pp. 1291-1308.

[14] Soba, D., Michard, A., Toteu, S. F., Norman, D. I., Penaye, J., Ngako, V., Nzenti, J. P., Dautel, D. 1991. Données géochronologiques nouvelles ( $\mathrm{Rb}-\mathrm{Sr}, \mathrm{U}-\mathrm{Pb}$ et $\mathrm{Sm}-\mathrm{Nd}$ ) sur la zone mobile pan-africaine de l'Est Cameroun: âge Protérozoïque supérieur de la série du Lom, Comptes Rendus l'Académie Science. Vol. 312, pp. 1453-1458.

[15] Toteu, S. F., Penaye, J., Deloule, E., Van Schmus, W. R., Tchameni, R. 2006a. Diachronous evolution of volcanosedimentary basins north of the Congo craton: insights from $\mathrm{U}-\mathrm{Pb}$ ion microprobe dating of zircons from the Poli, Lom and Yaounde Series (Cameroon). J. African Earth Sciences. Vol. 44, pp. 428-442.

[16] Toteu, S. F., Penaye, J., Poudjom, D. Y. 2004. Geodynamic evolution of the Pan-African belt in Central Africa with special reference to Cameroon. Canadian J. Earth Science. Vol. 41, pp. 73-85.

[17] Foumena, W. C., Bamenjo, J. N. 2013. Artisanal Mining - A challenge to the Kimberly Process: A case study of the Kadey Division, East Region of Cameroon, RELUFA Extractive Industries Programme Team. http://www.relufa.org/documents/BOOKENGLISH_NET.pdf. Accessed 24 February 2017

[18] Salminen, R., Tarvainen, T., Demetriades, A., Duris, M., Fordyce, F M., Gregorauskiene, V., Kahelin, H., Kivisilla, J., Klaver, G., Klein, H., Larson, J. O., Lis, J., Locutura, J., Marsina, K., Mjartanova, H., Mouvet, C., O'Connor, P., Odor, L., Ottonello, G., Paukola, T., Plant, J. A., Reimann, C., Schermann, O., Siewers, U., Steenfelt, A., Van der Sluys, J., deV ivo, B., Williams, L. 1998. FOREGS Geochemical mapping field manual. Geol. survey of Finland, Guide 47, p. $16-21$.

[19] Freeze, R. A., Cherry, J. A. 1979. Groundwater. Prentice-Hall, Englewood Cliffs. 604 p.

[20] WHO, 2011. Guidelines for Drinking-Water Quality, Fourth Edition, Geneva, 564 p.

[21] Njitchoua, R., Ngounou, N. B. 1997. Hydrogeochemistry and environmental isotope investigations of the North Diamare plain, Northern Cameroon. J. African Earth Sciences. Vol. 25, pp. 307-316.

[22] Rose, 2002. Comparative major ion geochemistry of piedmont streams in the Atlanta, Georgia region: possible effects of urbanization. Environ. Geol. Vol. 42, pp. 102-113. 
[23] Appelo, C. A. J., Postma, D. 1996. Geochemistry, groundwater and pollution. A. A. Balkema Publi. Leiden, 683 p.

[24] Tiwari, A. K., Singh, A. K. 2014. Hydrogeochemical investigation and groundwater quality assessment of the Pratapgarh District, Uttar Pradesh. Geol. Soc. India. Vol. 83, pp. 329-343.

[25] Salomons, W. 1995. Environmental impact of metals derived from mining activities: processes, predictions, prevention. J Geochem Explor. Vol. 52, pp. 5-23.

[26] Piper, A. M. 1944. A graphical procedure in the geochemical interpretation of water analysis. Transactions, American Geophysical Union. Vol. 25, pp. 914-928.

[27] Kamtchueng, B. T., Fantong, W. Y., Wirmvem, M. J., Tiodjio, R. E., Takounjou, A F., Ndam Ngoupayou, J. R., Kusakabe, M., Zhang, J., Ohba, T., Tanyileke, G., Hell, J. V., Ueda, A. 2016. Hydrogeochemistry and quality of surface water and groundwater in the vicinity of Lake Monoun, West Cameroon: approach from multivariate statistical analysis and stable isotopic characterization. Environ. Monit. Assess. 8: 524. [doi 10.1007/s10661-016-5514-x].

[28] Tamez-Mélendez, C., Hernandez-Antonio, A., Gaona-Zanella, P. C., Ornelas-Soto, N., Mahlknecht, J. 2016. Isotope signatures and hydrochemistry as tools in assessing groundwater occurrence and dynamics in a coastal arid aquifer. Environ. Earth Sci. [doi 10.1007/s12665-016-5617-2].

[29] Ahialey, E. K., Kortatsi, B. K., Anornu, G. K., Kaka, E. A., Dartey, G. 2015. Hydrogeochemical processes influencing groundwater quality in the Black Volta Basin of Ghana. Res. J. Appl. Sc. Enginer. Technol. Vol. 11 pp. 975-982.

[30] Edjah, A. K. M., Akiti, T. T., Osae, S. 2015. Hydrogeochemistry and isotope hydrology of surface water and groundwater systems in the Ellembelle district, Ghana, West Africa. Appl. Water Sci. [doi 10.1007/s13201-015-02733].
[31] Kim, K., Rajmohan, N., Kim, H. J., Kim, S. H., Hwang, G. S., Yun, S. T., Gu, B., Cho, M. J., Lee, S. H. 2005. Evaluation of geochemical processes affecting groundwater chemistry based on mass balance approach: A case study in Namwon, Korea. Geochem. J. Vol. 39, pp. 357-369.

[32] Fisher, R. S., Mullican, F. W. 1997. Hydrochemical evolution of sodium-sulphate and sodium-chloride groundwater beneath the Northern Chihuahuan Desert. Hydrogeol. J. Vol. 5, pp. 14 16.

[33] Singh AK, Mondal GC, Singh PK, Singh TB, Tewary BK (2005). Hydrochemistry of reservoirs of Damodar River basin, India: weathering processes and water quality assessment. Environ. Geol. 8: 1014-1028.

[34] Ouyang, Y., Nkedi-Kizza, P., Wu, Q. T., Shinde, D., Huang, C. H. 2006. Assessment of seasonal variations in surface water quality. Water Res. Vol. 40, pp. 3800-3810.

[35] Butler, J. N. 1981. Carbon Dioxide Equilibria. Lewis Publishers, Chelsea, Michigan. p. 116-118.

[36] Stumm, W., Morgan, J. J. 1981. Aquatic Chemistry, An Introduction Emphasising Chemical Equilibria in Natural Waters 2nd edition. John Wiley \& Sons, Inc, New York. p. 526-538.

[37] Ako, A. A., Shimada, J., Hosono, T., Ichiyanagi, K., Nkeng, G. E., Fantong, W. Y., Takem, G. E. E., Njila, N. R. 2011. Evaluation of groundwater quality and its suitability for drinking, domestic, and agricultural uses in the Banana Plain (Mbanga, Njombe, Penja) of the Cameroon Volcanic Line. Environ. Geochem Health. Vol. 33, pp. 559-575.

[38] Wirmvem, M. J., Ohba, T., Fantong, W. Y., Ayonghe, S. N., Suila, J. Y., Asaah, A. N. E., Tanyileke, G., Hell, J. V. 2013 b. Hydrogeochemistry of shallow groundwater and surface water in the Ndop plain, North West Cameroon. African J. Environ. Science and Technol. Vol. 7, No. 6, pp. 518-53. 